\title{
DISKRIMINASI RASIAL DAN ETNIS DALAM PERSPEKTIF HUKUM INTERNASIONAL
}

\author{
Defira Martina Adrian ${ }^{1}$, Fence M. Wantu ${ }^{2}$, Abdul Hamid Tome ${ }^{3}$ \\ 1,2,3, Fakultas Hukum Universitas Negeri Gorontalo, Jl. Jendral Sudirman No.6, Gorontalo, 96128 \\ defiraadrian11@gmail.com, fenceonetwo@yahoo.com, hamidtome@ung.ac.id
}

\begin{abstract}
Abstrak
Tujuan penelitian ini untuk mengetahui dan menganalisa Politik Hukum Pemerintah Indonesia dalam mencegah isu Rasialisme dan Etnis, juga untuk mengetahui Politik Hukum Pemerintah Indonesia dalam mencegah isu Rasialisme dan Etnis dikaji melalui aturan Hukum Internasional. Jenis Penelitian yang digunakan peneliti adalah jenis penelitian normatif, adapun pendekatan yang digunakan dalam penelitian ini antara lain: Pendekatan Perundang-Undangan (Statue Approach) dan Pendekatan Kasus (Case Approach). Hasil penelitian menggambarkan bahwa pelaksanaan diskriminasi ras dan etnis masih kerap terjadi dalam masyarakat. Indonesia sendiri sudah mempunyai aturan yang dinilai bagus untuk menangani dan menghapus kasus diskriminasi rasial dan etnis namun masih banyak yang belum mengetahui dan mendengar tentang aturan tersebut. Maka dari itu, aturan yang ada dinilai kurang populer karena kurangnya sosialisasi sehingga implementasi terjadi hanya seputar penindakan namun masih lemah pada aspek pencegahan. Maka dari itu pemerintah harus lebih banyak memberikan edukasi terhadap rakyat tentang adanya peraturan mengenai penghapusan diskriminasi rasial dan etnis ini. Sehingga, pelanggaran berupa penghinaan suatu ras dan etnis tertentu tidak lagi dianggap biasa atau sepele dan peraturan ini juga dapat berjalan dengan baik.
\end{abstract}

\section{Kata Kunci: Diskriminasi, Rasial, Etnis, Hukum Internasional}

\begin{abstract}
The purpose of this research is to find out and analyze the Legal Politics of the Indonesian Government in preventing the issue of racism and ethnicity being studied through the rules of international law. The type of research used by researchers is a type of normative research, while the approaches used in this study include: the Statue Approach and the Case Approach. The results of the study describe that the discrimination about racial and ethnic is still happening in society, Indonesia is known to have the regulation that arrange about the discrimination of racial and ethnic but the implementation is considered not yet effective in ensnaring perpetrators of racism or racial and ethnic discrimination. The law is less popular due to lack of socialization, therefore the government must provide more education to the people about the existence of a law on the elimination of racial and ethnic discrimination. Thus, violations in the form of insulting a certain race and ethnicity are no longer considered ordinary or trivial and this Law can also run well.
\end{abstract}

\section{Keywords: Discrimination, Racial, Ethnic, International Law}




\section{PENDAHULUAN}

\section{Latar Belakang}

Indonesia adalah negara yang menganut tradisi hukum Eropa Kontinental atau sering disebut dengan civil law. Tradisi civil law ditandai dengan sistem hukum tertulis yang merupakan syarat utama (the main requirement) dalam penyelenggaraan negara. ${ }^{1}$

Indonesia dalam konstitusi merupakan negara hukum yang perwujudannya tercermin ke dalam peraturan perundangundangan yang dibuat untuk membatasi kekuasaan negara (pemerintah) dan memberi pedoman bagi rakyat dalam menjalankan aktivitasnya sebagai warga negara. $^{2}$

Hubungan antara masyarakat papua dengan pemerintah Indonesia secara konsisten telah mengalami konflik semenjak wilayah papua berintegrasi ke negara Indonesia pada tahun 1963 berdasarkan perjanjian New York antara Indonesia dengan Netherlands pada tahun $1962^{3}$
Indonesia sendiri jika dilihat dari perjalanan Pancasila yang memiliki sejarahnya sendiri dalam kehidupan berbangsa dan bernegara, yang sampai saat ini belum menunjukan keharmonisan hidup setiap komponen negara, mengharuskan warga Indonesia untuk memikirkan kembali jalan terbaik bagi perjalanan kehidupan berbangsa dan bernegara dalam koridor Pancasila. Pancasila adalah ikhtiar kebangsaan yang perlu dijaga serta dirawat demi keutuhan negara sehingga Pancasila tidak hanya slogan semata dengan mengatakan "Saya Indonesia, Saya Pancasila". ${ }^{4}$

Isu serta masalah rasisme terhadap orang Papua dan juga kerusuhan yang terjadi di Papua mencatat riwayat baru pada panggung politik nasional. Ini telah membawa dan mengingatkan kita pada riwayat masalah yang serupa, yaitu isu separatism atau disebut the issue of self determination. 5 Kasus yang terjadi di Surabaya dan Malang, dilansir The Conversation, Minggu (8/9), tanggal 17

Sosial dan Ilmu Politik, Vol. 21 Issue 2, (hlm 1). (diterjemahkan oleh peneliti: "Defira Martina Adrian).

4 Tome, Abdul Hamid, 2020, "Membumikan Pancasila: Upaya Pelembagaan Nilai Pancasila Dalam Kehidupan Masyarakat Desa", Jurnal Al-'Adl, Vol. 13, No. 1, 2020, (hlm 1).

5 Max Lane, 2019, "The Papuan Question in Indonesia: Recent Developments", Researches At Iseas - Yusof Ishak Institute Analyse Current Events, Vol. 9 No. 74, (hlm 3). (diterjemahkan oleh peneliti: Defira Martina Adrian) 
Agustus 2019, peristiwa terjadi ketika polisi menangkap 43 mahasiswa Papua di asrama mereka Surabaya, Jawa Timur karena dituduh telah menodai bendera Indonesia Merah Putih selama Anugerah Hari Kemerdekaan. Polisi menggedor gerbang asrama Papua di Surabaya, alasannya karena mereka melihat ada bendera Merah Putih yang dipasang pemerintah Kota Surabaya jatuh ke selokan. Secara bertahap polisi dan ormas mendatangi dan mengepung asrama itu selama 24 jam. Polisi meneriakkan berbagai penghinaan rasis, dan menggunakan gas air mata untuk mereka keluar. Namun esoknya, 43 mahasiswa Papua yang ditangkap itu dibebaskan oleh polisi karena tidak memiliki bukti kuat jika para penghuni menghina lambang negara.

Kejadian ini mengakibatkan gelombang orang di Papua menumpahkan kekecewaannya di Jayapura, Ibu Kota Papua, dan di Manokwari, Ibu Kota Papua Barat, serta Kota Sorong. Di Jayapura, lautan manusia berdemo jalan kaki sepanjang 18 kilometer dari Waena, pusat keramaian di kota itu, menuju kantor gubernur; menuntut rasialisme terhadap Papua harus dihentikan. Gubernur Papua, Lukas Enembe saat itu tegas

6 Ratnasari, Fadhila Eka, 2020, dilansir dari Berita Politik Dunia, https://matamatapolitik.com/membicarakan- berkata bahwa "kami bukan bangsa monyet, kami manusia."6

Kasus yang terjadi di Makassar juga memiliki kemiripan dengan kasus yang terjadi di Surabaya, pada saat itu sekitar pukul 18.00 sekitar 20 orang yang diduga anggota ormas mendatangi asrama mahasiswa Papua di Kota Makassar. Mahasiswa yang berjumlah 30 orang pun kaget kedatangan tamu tak diundang. Mereka lantas mendatangi ormas yang sudah memasuki pekarangan asrama mereka dengan niat untuk bicara baik-baik, namun menurut salah satu mahasiswa, para ormas mulai bicara dengan nada tinggi soal masalah yang ada di Papua, namun mahasiswa menolak membicarakan itu karena menurut mereka, tujuan mereka di Makassar hanya ingin belajar. Situasi pun kemudian memanas sampai akhirnya salah satu anggota ormas mulai menunjuk batang hidung salah satu mahasiswa dan menyuruhnya untuk diam. Situasi menjadi semakin tidak kondusif, para ormas mulai melemparkan batu dan botol ke asrama mahasiswa Papua tersebut. Awalnya, para mahasiswa hanya tetap diam dan berlindung didalam, namun seiring berjalannya waktu, mereka sadar jika dibiarkan maka ini akan merusak asrama analisis/ (diakses pada tanggal 10/25/2020). 
mereka, terjadilah aksi saling melempar batu. Selain batu, rupanya massa ormas juga menggunakan panah dan mengakibatkan satu mahasiswa terluka di bagian punggung dan kemudian dilarikan ke rumah sakit. ${ }^{7}$

Berdasarkan data dari Komisi Nasional Hak Asasi Manusia terkait dengan survey yang dilakukan untuk mengevaluasi penilaian publik terhadap upaya pengahapusan diskriminasi ras dan etnis serta sebagai bahan refleksi dari pelaksanaan Undang Undang No. 40 Tahun 2008, survey dilakukan kepada 1.207 warga (17-65 tahun) di 34 Provinsi di Indonesia mencatat sedikitnya 101 kasus diskriminasi ras dan etnis yang dilaporkan kepada mereka. Pelanggaran tersebut meliputi pembatasan terhadap pelayanan publik, maraknya politik etnisitas atau identitas, pembubaran ritual adat, diskriminasi atas hak kepemilikan tanah bagi kelompok minoritas, serta akses ketenagakerjaan yang belum berkeadilan. Hal yang menarik adalah, angka tertinggi dicatat pada tahun 2016 dengan 38 kasus.

Namun berdasarkan survey $70 \%$ menjawab belum pernah melihat

7 Mohmmad Bernie, 2019, dilansir berita tirto.id https://tirto.id/kronologi-penyerangan-asrama-papuadi-makassar-versi-mahasiswa-egAJ (diakses pada tanggal 10/25/2020).

8 Ign. L. Adhi Bhaskara, 2018, dilansir dari tirto.id https://tirto.id/survei-komnas-ham-diskriminasi-etnisras-masih-terus-ditolerir-dahP (diakses pada tanggal 24 Oktober 2020). diskriminasi ras dan etnis sementara $90 \%$ menjawab belum pernah pengalami tindakan diskriminasi ras dan etnis. Temuan ini memiliki dua kemungkinan, tindakan diskriminasi ras dan etnis memang benarbenar sangat jarang terjadi atau, yang mengkhawatirkan adalah pemahaman masyarakat tentang bentuk-bentuk diskriminasi ras dan etnis selama ini tidak cukup memadai sehingga menganggap tindakan-tindakan diskriminasi tersebut bukan merupakan tindakan pelanggaran hukum yang serius. ${ }^{8}$ Dalam 2 tahun ini, kurun waktu 2018-2019 kita mencatat ada kurang-lebih ada 30 kasus terkait dengan dugaan pelanggaran HAM yang dialami mahasiswa Papua di Indonesia. Sebut saja di Surabaya ada 9 kasus, ini Surabaya dan Malang yang baru saja terjadi. ${ }^{9}$

Melihat dari kasus yang terjadi di Surabaya dan Makassar ini dapat kita kaitkan dengan pandangan dari hukum internasional. Pada Pasal 1 UDHR tersebut, kita dapat memahami prinsip kebebasan, kesetaraan, dan persaudaraan. Hal ini berarti bahwa setiap orang mempunyai kedudukan yang

9 Jefrie Nandy Satria, 2019, dilansir dari detikNews https://news.detik.com/berita/d-4676722/ylbhikecam-dugaan-diskriminasi-pada-mahasiswa-papuadi-surabaya (diakses pada tanggal 22 Desember 2020). 
setara antara satu dengan yang lain dalam kehidupan individu maupun kehidupan sosialnya.

Prinsip antidiskriminasi dengan tegas juga dijelaskan pada Pasal 2 Deklarasi Univiersal HAM (Universal Declaration of Human Rights) yang berbunyi : "Setiap orang berhak atas semua hak dan kebebasankebebasan yang tercantum di dalam Pernyataan ini tanpa perkecualian apapun, seperti ras, warna kulit, jenis kelamin, bahasa, agama, politik atau pendapat yang berlainan, asal mula kebangsaan atau kemasyarakatan, hak milik, kelahiran ataupun kedudukan lain", dengan kata lain dalam perspektif hak asasi manusia tidak boleh ada perlakuan diskriminatif yang ditujukan kepada kelompok masyarakat tertentu. Penegasan mengenai prinsip kesetaraan dan antidiskriminasi dalam pelaksanaan hak asasi manusia dapat juga dicermati dalam instrumen hukum internasional tentang hak asasi manusia antara lain adalah Konvenan Internasional tentang Hak-Hak Ekonomi, Sosial, dan Budaya (The International Covenant on Economic, Social and Culture Right) yang telah diratifikasi oleh Negara Republik Indonesia sebagaimana diatur dalam Undang-Undang Nomor 11 Tahun 2005 dan juga The International Covenant on Civil and
Politic Rights yang telah diratifikasi melalui Undang-Undang Nomor 12 Tahun 2005.

Isu mengenai diskriminasi ini tidak selesai dengan hanya dikatakan, pun tidak hanya ditulis dalam konstitusi, karena untuk menghentikan praktik dan perilaku-perilaku diskriminasi ini tidak cukup jika hanya dimuat dalam Undang-Undang jika ternyata pada kenyataannya belum efektif, dan juga kasus diskriminasi makin marak dibincangkan. Dalam mengatasi dan menangani kasus dan isu-isu pelanggaran hak asasi manusia, terutama diskriminasi rasial dan etnis ini sendiri, penegakan hukum merupakan salah satu instrumen penting yang sangat diperlukan dan harus bersinergi dengan instrumen-instrumen lainnya, maka dari itu penegakan hukum nasional dan internasional sangat dibutuhkan dan harus berjalan sinergis agar bisa menghapus isu diskriminasi rasial dan etnis ini.

\section{Rumusan Masalah}

Berdasarkan latar belakang masalah yang telah dijabarkan, maka peneliti mengangkat rumusan masalah sebagai berikut:

1. Bagaimana Politik Hukum Pemerintah Indonesia Dalam Mencegah Isu Rasialisme Dan Etnis?

2. Bagaimana Politik Hukum Pemerintah Indonesia Dalam Mencegah Isu 
Rasialisme Dan Etnis Dikaji Melalui Aturan Hukum Internasional?

\section{Metode Penelitian}

Adapun pendekatan yang digunakan dalam penelitian ini antara lain:

1. Pendekatan $\rightarrow$ Pendekatan PerundangUndangan (Statue Approach) dan Pendekatan Kasus (Case Approach).

\section{Metode Pengumpulan Data $\rightarrow$} Pengumpulan bahan hukum dalam penelitian ini menggunakan Library Research atau penelitian pustaka yaitu teknik yang dilakukan dengan cara mempelajari, mendalami, dan menganalisis dari jumlah bahan bacaan, yang bersumber dari buku, jurnal, majalah, koran, atau karya tulis lainnya yang relevan dengan topik, fokus atau variabel penelitian. Disamping itu, penulis berusaha mendapatkan dan mempelajari data dari buku-buku keterangan yang ada hubungannya dengan penulisan ini.

3. Teknik Analisa Data $\rightarrow$ Analisis bahan hukum ialah kegiatan dalam penelitian yang berupa melakukan kajian terhadap hasil pengolahan data yang dibantu dengan teori-teori yang telah didapatkan sebelumnya. Jenis penelitian hukum normative ialah penelitian yang

10 Law Review, Fakultas Hukum Universitas Pelita Harapan, Vol. V No. 3, Maret 2006, hlm 94. ditujukan untuk mengkaji kualitas dari norma hukum itu sendiri, sehingga seringkali penelitian hukum normatif diklasifikasi sebagai penelitian kualitatif. ${ }^{10}$ Analisis data kualitatif ialah uraian yang dilakukan penulis terhadap data-data yang terkumpul dengan tidak menggunakan angka-angka, tapi berdasarkan pada peraturan perundangundangan, pandangan pakar, jurnal, dan bahan hukum lainnya untuk memberikan penjelasan dan kesimpulan terkait dengan Analisis Diskriminasi Rasial Dan Etnis Ditinjau Dari Hukum Internasional, dengan menggunakan pendekatan kualitatif penulis memusatkan perhatiannya pada prinsipprinsip umum yang mendasari perwujudan satuan-satuan gejala yang ada pada kehidupan manusia. ${ }^{11}$

\section{PEMBAHASAN}

\section{A. Politik Hukum Indonesia Dalam Mencegah Isu Rasial Dan Etnis.}

Indonesia adalah negara yang menganut tradisi hukum Eropa Kontinental atau sering disebut dengan civil law. Tradisi civil law ditandai dengan sistem hukum tertulis yang merupakan syarat utama (the main

\footnotetext{
11 Ashofa, Burham, "Metode Penelitian Hukum," (Jakarta:Rineka Cipta, 2010), hlm 123.
} 
requirement) dalam penyelenggaraan negara. ${ }^{12}$

Indonesia dalam konstitusi merupakan negara hukum yang perwujudannya tercermin ke dalam peraturan perundangundangan yang dibuat untuk membatasi kekuasaan negara (pemerintah) dan memberi pedoman bagi rakyat dalam menjalankan aktivitasnya sebagai warga negara. ${ }^{13}$ Sebagai konsekuensi dari negara demokrasi konstitusional, maka konstitusi sejatinya harus memuat aspek yang bersifat fundamental, meliputi pengaturan mengenai jaminan terhadap hak asasi manusia dari warga negaranya. ${ }^{14}$

Praktik Diskriminasi Rasial menjadi sumber utama konflik di berbagai belahan dunia. Hal ini juga pernah disampaikan oleh Sekertaris Jendral Perserikatan BangsaBangsa (PBB) dalam sambutannya pada peringatan ke-51 Universal Hak Asasi Manusia (DUHAM) pada 9 Desember 1999. Kofi Annan dengan jelas mengatakan bahwa diskriminasi rasial menjadi ancaman utama dalam perdamaian dunia. Hal ini juga meliputi negara kita, yaitu Indonesia.

12 Tijow, Lusiana Margareth, 2020, Kedudukan Peraturan Desa Dalam Sistem Pembentukan Peraturan Perundang-undangan Nasional, Jurnal Ius Civile, Vol. 4, No. 2. (hlm 1).

13 Achir, Nuvazria, 2020, Anotasi Normatif Terhadap Peraturan Daerah Tentang Transparasi, Jambura Law Review, Vol. 2, Issue 01, (hlm 3).
Perbedaan seringkali menjadi alasan terjadinya perpecahan, peperangan antarkelompok, dengan mengangkat perbedaan suku, agama dan ras sebagai simbol permusuhan. Selama periode sebelum 1998, tidak ada upaya negara untuk melakukan penghapusan diskriminasi rasial, bahkan tidak jarang fakta-fakta diskriminasi tersebut tidak diakui sebagai diskriminasi. Kemudian baru pada tahun 1999, setelah terjadi reformasi dengan mundurnya Soeharto sebagai Presiden Republik Indonesia, negara Republik Indonesia meratifikasi International Convention on Elimination of All Forms Racial Discrimination pada tahun 1999, karena desakan komunitas Internasional.

Pada Indonesia pasca Orde Lama, persoalan kata "diskriminasi rasial" nyaris tidak terdengar, dan memang tidak disebutkan, bahkan dilarang diperbincangkan. Rasisme diperhalus dengan istilah SARA (Suku, Agama, Ras, dan Antargolongan). Implikasinya, segala yang berbau rasisme dikatakan SARA, yang artinya tidak boleh diributkan dan dibiarkan begitu saja. Pada masa pemerintahan Orde Baru,

\footnotetext{
14 Nggilu, Novendri M., dan Fence M. Wantu, 2020, Menapaki Jalan Konstitusional Menuju Zaken Cabinet : Ikhtiar Mewujudkan Pemerintah Berkualitas Konstitusi, Jurnal Hukum, Vol. 15, No. 1, (hlm 2).
} 
perlakuan disriminasi terhadap ras dan etnis tertentu semakin terbuka dan menguat khususnya di bidang pendidikan, ekonomi, kependudukan dan agama. Sesudahnya jatuhnya rezim Orde Baru, yang selama 32 tahun dihiasi dengan beragam pelanggaran Hak Asasi Manusia (HAM), rezim reformasi memiliki keinginan untuk menciptakan demokrasi di seluruh aspek kehidupan, tegaknya kedaulatan hukum dan penghormatan terhadap hak-hak asasi manusia tanpa diskriminasi. Namun alih-alih kehidupan demokrasi yang sudah lama diidamkan itu berlangsung dengan kedamaian, yang terjadi malah sebaliknya, konflik diskriminasi kembali muncul.

Salah satu cara mencegah konflik diskriminasi dan rasial, kita harus mengetahui jenis dan tipe konfliknya terlebih dahulu merupakan Secara umum, dalam teori konflik terdapat dua jenis konflik. Konflik vertikal dan horizontal, terkait dengan diskriminasi rasial dan etnis ini sendiri termasuk didalam konflik horizontal. Konflik horizontal adalah konflik yang terjadi di kalangan masyarakat (massa) sendiri.

Konflik horizontal terjadi antara kelompok masyarakat atau suku yang satu dengan kelompok atau suku lainnya. Konflik horizontal dalam konteks Papua adalah antara kelompok atau suku orang Papua dengan kelompok atau suku non Papua, dan di antara kelompok atau suku orang Papua sendiri. Selain jenis konflik, kita perlu mengenal tipe konflik. Tipe konflik akan menggambarkan persoalan sikap, perilaku, dan situasi yang ada. Tipe konflik ini sendiri terbagi atas empat, yaitu, tipe konflik tanpa konflik, tipe konflik laten dan tipe konflik terbuka dan konflik di permukaan.

Dari empat tipe konflik tersebut kita dapat menganalisis tipe konflik yang terjadi di Papua. Tipe konflik yang terjadi di Papua yaitu tipe konflik laten dan terbuka. Tipe konflik laten adalah suatu keadaan yang di dalamnya terdapat banyak persoalan, sifatnya tersembunyi dan perlu diangkat ke permukaan agar bisa ditangani.

Sementara itu, tipe konflik terbuka menggambarkan situasi di mana konflik sosial telah muncul dan berakar dan sangat nyata, dan memerlukan berbagai tindakan untuk mengatasi akar penyebab dan berbagai efeknya. Adapun tipe konflik di permukaan menggambarkan konflik yang memiliki akar konflik yang dangkal atau lemah dan muncul karena kesalahpahaman mengenai sasaran, yang dapat diatasi dengan meningkatkan dialog terbuka. Tipe konflik lanten disebut sebagai tipe konflik yang cocok dikarenakan banyaknya sumber konflik sebagai pokok persoalannya, salah satunya yaitu pelanggaran hak asasi manusia dan diskriminasi dan marginalisasi terhadap 
orang Papua, yang bahkan telah berlangsung sejak integrasi Papua tahun 1963, marginalisasi dan diskriminasi telah menjadi persoalan yang serius pada masa lalu di Papua.

Tidak hanya itu, ketika memasuki era Reformasi di Indonesia tahun 1998, Presiden B.J Habibie telah mengeluarkan Instruksi Presiden Nomor 26 Tahun 1998 tentang Penghentian Penggunaan Istilah Pribumi Nonpribumi serta meniadakan pembedaan dalam segala bentuk. Dengan demikian, prinsip nondiskriminasi menyatu dalam prinsip kesetaraan. Prinsip kesetaraan memastikan bahwa tidak seorang pun dapat meniadakan hak asasi orang lain karena faktor-faktor luar. Seperti ras, warna kulit, jenis kelamin, bahasa, agama, politik, dan ideologi, kebangsaan, kepemilikan, status kelahiran dan lainnya.

Berbagai dokumen sejarah konflik Papua telah mencatat bahwa kebijakan pertahanan dan keaman di Papua sangat erat kaitannya dengan perkembangan politik dan pemerintahan, jika kita pikirkan kembali, baik pemerintah maupun rakyat pun juga harus berpegang dan kembali ke Pancasila, agar terbentuknya moral sehingga kita tidak akan melakukan tindakan diskriminasi, seperti yang ada pada Pancasila.

Lalu bagaimana politik hukum pemerintah Indonesia mencegah isu serta persoalan yang berlarut-larut ini? Demi mencapai tujuan negara yang berpijak pada Undang-undang Dasar 1945 dan demi menjadikan negara Indonesia sebagai negara yang aman dan damai, saat ini Indonesia sudah membuat pengaturan yang membahas tentang diskriminasi, yang pasal-pasalnya berisi tentang penghapusan diskriminasi rasial dan etnis, yaitu Undang-Undang Republik Indonesia Nomor 40 Tahun 2008 Tentang Penghapusan Diskriminasi Ras Dan Etnis. Ruang lingkup pengaturan dari Undang-Undang ini sendiri berbicara tentang apa yang dimaksud dengan diskriminasi ras dan etnis. Dalam undang-undang ini, mulai dari pengertian tentang apa itu diskriminasi rasial, apa itu ras, apa itu etnis tertuang sangat jelas pada Pasal 1 Ayat (1), (2) dan (3). Sementara, bagaimanakah tindakan diskriminasi rasial dan etnis itu dijelaskan pada Pasal 1 Ayat (5) dan kembali dituangkan secara lebih rinci lagi pada Pasal 4. Tujuan dibentuknya undang-undang ini tentu saja untuk menghapus segala bentuk diskriminasi dan mewujudkan keharmonisan antara warga Negara Indonesia. Hal ini tentu saja dilaksanakan dengan didasari oleh asas persamaan, kebebasan, keadilan dan nilainilai kemanusiaan universal dengan tetap memerhatikan nilai-nilai agama, sosial, budaya dan hukum yang berlaku di Indonesia. Pengaturan terkait asas dan 
tujuan dapat kita lihat pada Pasal 2 dan Pasal 3.

Poin paling penting dalam undangundang ini tertuang pada Pasal 5, Pasal 6 dan Pasal 7 yaitu mengenai pemberian perlindungan dan jaminan. Seperti yang dijelaskan pada ketiga pasal ini bahwa perlindungan, kepastian serta kesamaan kedudukan dalam hukum kepada semua warga negara Indonesia untuk hidup bebas dari diskriminasi ras dan etnis, hal ini berarti bahwa tidak perduli apa ras-nya, apa warna kulitnya, apa agamanya serta dari etnis mana dia berasal, semua warga negara wajib untuk menghargai perbedaan tersebut dan hidup berdampingan tanpa adanya diskriminasi. Perlindungan bagi seluruh warga negara Indonesia dari segala bentuk diskriminasi rasial dan etnis ini diselenggarakan oleh pemerintah, baik pemerintah pusat maupun daerah. Tidak hanya pemerintah, namun peraturan dan perlindungan ini juga berlaku dan melibatkan partisipasi warga negara Indonesia sesuai dengan ketentuan perundang-undangan agar terciptanya masyarakat yang harmonis dan bebas dari diskriminasi.

Pemerintah dalam pelaksanaan penyelenggaraan perlindungan ini wajib untuk memberikan perlindungan yang efektif kepada warga negara atau kepada pihak yang menjadi korban diskriminasi dan menjamin untuk terlaksananya upaya penegakan hukum secara efektif terhadap tindakan diskriminasi yang terjadi, selain itu juga menjamin setiap warga negara atau pihak yang menjadi korban diskriminasi memperoleh pertolongan, penyelesaian dan penggantian yang adil atas segala kerugian serta penderitaan yang terjadi akibat diskriminasi rasial dan etnis ini.

Segala upaya untuk mendukung dan mendorong penghapusan diskriminasi ras dan etnis ini juga menjamin aparatur negara dan lembaga-lembaga pemerintah bertindak sesuai ketentuan perundang-undangan.

Selanjutnya, sebagaimana yang telah dijelaskan diatas, dapat dikatakan bahwa tidak hanya pemerintah namun rakyat juga ikut berpartisipasi dalam penghapusan diskriminasi rasial dan etnis ini. Ketentuan mengenai hak dan kewajiban serta peran warga negara telah diatur pada Pasal 9, Pasal 10, Pasal 11, dan Pasal 12.

Selain itu, walaupun Indonesia sudah membuat sebuah aturan khusus yang berupa Undang-undang nomor 40 Tahun 2008 yang mengatur tentang diskriminasi ini sendiri, namun tidak jarang pula banyak dari masyarakat yang belum mengetahui tentang adanya Undang-undang Nomor 40 Tahun 2008 Tentang Penghapusan Diskriminasi Ras dan Etnis ini. Seperti contohnya, pada Pasal 5, Pasal 6 dan Pasal 7 yang membahas 
tentang jaminan bagi para warga negara atau pihak yang mengalami diskriminasi rasial dan etnis. Masih banyak pihak yang menjadi korban dari diskriminasi rasial dan etnis yang merasa kurang mendapat perlindungan dari pemerintah. Isu-isu diskriminasi rasial dan etnis ini masih sering dikesampingkan, hal inilah yang membuat para pihak yang mengalami diskriminasi kurang dilindungi dan dijamin, terlebih oleh pemerintah. Tidak hanya itu, pada Pasal 9, Pasal 10, Pasal 11, dan Pasal 12 yang membahas tentang hak, kewajiban serta peran warga negara juga masih sering dikesampingkan, karena pada kenyataannya masih banyak warga negara Indonesia sendiri yang melemparkan ujaran kebencian, bahkan candaan yang bersifat berlebihan atau yang biasa disebut "candaan rasis". Hal terkait diskriminasi rasial dan etnis ini masih dianggap sepele oleh masyarakat.

Seperti kasus-kasus penghinaan terkait warna kulit dan ras serta etnis Papua yang selalu saja menjadi konflik. Padahal jelasjelas hal ini telah diatur dalam undangundang agar menciptakan masyarakat yang harmonis dan menghapuskan segala bentuk diskriminasi rasial dan etnis. Salah satu Pasal yang telah berjalan dengan cukup baik terkait dengan Undang-undang Nomor 40 Tahun 2008 ini adalah tentang pengawasan, sebagaimana yang diatur pada Pasal 8. Pada pasal 8 Ayat (1) berbunyi: "Pengawasan terhadap segala bentuk upaya penghapusan diskriminasi ras dan etnis dilakukan oleh Komnas HAM." Komnas HAM dalam hal ini telah menunjukkan kinerja yang bagus dan berjalan sesuai undang-undang ini sendiri. Upaya-upaya yang dilakukan oleh Komnas HAM dalam membantu penghapusan diskriminasi rasial dan etnis dinilai cukup baik karena Komnas HAM dianggap cukup tackle dalam menanggapi kasus-kasus diskriminasi rasial dan etnis.

Komnas HAM selalu melakukan pencarian fakta dan penilaian pada pihak yang diduga melakukan tindakan diskriminasi, hal ini sesuai dengan yang diatur oleh Pasal 8 Ayat (2). Selain itu, Komnas HAM juga selalu mengangkat isu diskriminasi rasial dan etnis ini agar tidak dikesampingkan dan memberikan rekomendasi pada pemerintah asal hasil pemantauan yang mereka lakukan.

Tidak hanya itu, Komnas HAM juga bahkan mengedukasi masyarakat agar lebih peka terhadap isu ini dengan mengeluarkan buku panduan mengenai ras dan etnis yang didalamnya memuat tentang diskriminasi rasial dan etnis serta kaum minoritas. Salah satu bentuk kontribusi Komnas HAM adalah membantu mengedukasi masyarakat dengan merilis videografis standar norma dan pengaturan tentang penghapusan 
diskriminasi ras dan etnis dan mengadakan sosialisasi webinar yang diselenggarakan baru-baru ini pada 14 Desember 2020 mengenai diskriminasi ras dan etnis ini sendiri dengan mengundang seluruh warga Indonesia untuk bergabung. Walaupun pemerintah sudah ikut terlibat, namun implementasi Undang-undang Nomor 40 Tahun 2008 tentang Penghapusan Diskriminasi Ras dan Etnis kurang populer karena kurangnya sosialisasi sehingga implementasi terjadi hanya seputar penindakan namun masih lemah pada aspek pencegahan. Undang-undang ini kurang populer karena kurangnya sosialisasi, maka dari itu pemerintah harus lebih banyak memberikan edukasi terhadap rakyat tentang adanya Undang-Undang mengenai penghapusan diskriminasi rasial dan etnis ini. Sehingga, pelanggaran berupa penghinaan suatu ras dan etnis tertentu tidak lagi dianggap biasa atau sepele dan UndangUndang ini juga dapat berjalan dengan baik.

\section{B. Politik Hukum Indonesia Dalam} Mencegah Isu Rasial Dan Etnis Dikaji Melalui Aturan Hukum Internasional.

Pada perjanjian-perjanjian internasional ini kita dapat menemukan halhal yang berkaitan dengan diskriminasi rasial dan etnis. Dalam tingkatan internasional, selain instrumen Konvensi Internasional Tentang Penghapusan Semua Bentuk
Diskriminasi Rasial, ada juga Penghukuman Kejahatan Pembedaan Warna Kulit (Apartheid).

Sedangkan dalam domain regional, prinsip non diskriminasi juga dijumpai dalam Piagam Afrika (Banjul) Tentang Hak Asasi Manusia, Konvensi Amerika Tentang Hak Asasi Manusia, Deklarasi Amerika Tentang Hak dan Tanggung Jawab Manusia, dan Konvensi Eropa Untuk Perlindungan Hak Asasi dan Kebebasan Fundamental dan Piagam Sosial Eropa.

Indonesia sendiri telah mengetahui betul tentang Deklarasi Universal Hak Asasi Manusia, sebagai negara anggota PBB telah telah berjanji untuk mencapai kemajuan dalam penghargaan dan penghormatan umum terhadap hak-hak asasi manusia dan kebebasan-kebebesan yang asasi, dalam kerja sama dengan Perserikatan BangsaBangsa telah memproklamasikan Deklarasi Universal Hak Asasi Manusia sebagai suatu standar umum untuk keberhasilan bagi semua bangsa dan semua negara. Indonesia pun telah membuat Undang-undang Nomor 39 Tahun 1999 Tentang Hak Asasi Manusia sebagai bentuk tanggung jawab moral dan hukum Indonesia sebagai anggota PBB dalam penghormatan dan pelaksanaan Deklarasi Universal HAM atau Universal Declaration of Human Rights (UDHR) tahun 1948 serta 
berbagai instrumen HAM lainnya mengenai HAM yang telah diterima Indonesia.

Mengenai definisi tentang Hak Asasi Manusia juga telah dijelaskan secara rinci pada Pasal 1 dan Pasal 2 dalam Undangundang Nomor 39 Tahun 1999 ini.

Sebagaimana yang dimuat dalam Universal Declaration of Human Rights (DUHAM) Article 2:

"Everyone is entitled to all the rights and freedoms set forth in this Declaration, without distinction of any kind, such as race, colour, sex, language, religion, political or other opinion, national or social origin, property, birth or other status. Furthermore, no distinction shall be made on the basis of the political, jurisdictional or international status of the country or territory to which a person belongs, whether it be independent, trust, non-self-governing or under any other limitation of sovereignty."

Artinya bahwa setiap orang berhak atas semua hak dan kebebasan-kebebasan yang tercantum di dalam Deklarasi ini dengan tidak ada pengecualian apa pun, seperti pembedaan ras, warna kulit, jenis kelamin, bahasa, agama, politik atau pandangan lain, asal-usul kebangsaan atau kemasyarakatan, hak milik, kelahiran ataupun kedudukan lain. Maka setiap orang wajib dilindungi hak asasi manuisianya tanpa ada pembedaan antara ras maupun etnis, dengan kata lain dalam perspektif hak asasi manusia tidak boleh ada perlakuan diskriminatif yang ditujukan kepada kelompok masyarakat tertentu.

Pasal 2 pada DUHAM ini juga selaras dengan Undang-undang Nomor 39 Tahun 1999 Tentang Hak Asasi Manusia Pasal 3 Ayat (3) yang mengatakan bahwa setiap orang berhak atas perlindungan hak asasi manusia dan kebebasan manusia tanpa diskriminasi. Ini berarti bahwa setiap warga negara Indonesia berhak untuk melindungi Hak Asasi Manusia mereka dari tindakan diskriminasi apapun, termasuk rasial dan etnis, dan juga hal ini selaras dan dibahas lebih detail pada Undang-undang Nomor 40 Tahun 2008 Tentang Penghapusan Diskriminasi Rasial Dan Etnis pada Pasal 9 yang juga berbunyi setiap negara berhak memperoleh perlakuan yang sama tanpa pembedaan ras dan etnis.

Selain dalam Article 2, hal-hal mengenai anti diskriminasi juga dimuat pada Article 7:

"All are equal before the law and are entitled without any discrimination to equal protection of the law. All are entitled to equal protection against any discrimination in violation of thic Declaration and against any incitement to such discrimination."

Artinya bahwa semua orang sama di depan hukum dan berhak atas perlindungan hukum yang sama tanpa diskriminasi. Semua berhak atas perlindungan yang sama terhadap setiap bentuk diskriminasi yang 
bertentangan dengan deklarasi ini, dan terhadap segala hasutan yang mengarah pada diskriminasi semacam ini.

Hal ini berarti bahwa tindakan segala tindakan diskriminasi, termasuk tindakan diskriminasi rasial dan etnis bertentangan pada prinsip anti diskriminasi dan bertentangan dengan DUHAM ini sendiri, maka bagi pihak yang mengalami tindakan diskriminasi ras dan etnis berhak untuk mendapat perlindungan yang sama. Article 7 pada DUHAM ini juga selaras dengan Pasal 3 Ayat (3) Undang-undang Nomor 39 Tahun 1999 dan Pasal 6 serta Pasal 9 dalam Undangundang Nomor 40 Tahun 2008.

Dalam kasus ini, sesuai dengan kajian hukum internasional, pemerintah Indonesia juga melakukan upaya dalam mencegah isu rasial dan etnis. Selain DUHAM dan Undangundang Nomor 39 Tahun 1999 Tentang Hak Asasi Manusia serta Undang-undang Nomor 40 Tahun 2008 Tentang Penhapusan Diskriminasi Rasial dan Etnis, pemerintah juga melakukan berbagai upaya untuk mencegah dikriminasi rasial dan etnis dengan meratifikasi berbagai perjanjian internasional yang pada intinya berkomitmen untuk menghapus segala jenis bentuk diskriminasi, khususnya bagi kaum minoritas. Perjanjian-perjanjian internasional yang sudah diratifikasi pemerintah Indonesia sejauh ini adalah
Konvenan Internasional tentang Hak-Hak Ekonomi, Sosial, dan Budaya (The International Covenant on Economic, Social and Culture Right) yang telah diatur dalam Undang-Undang Nomor 11 Tahun 2005 dan juga The International Covenant on Civil and Politic Rights yang telah diatur melalui Undang-Undang Nomor 12 Tahun 2005.

Walaupun pemerintah sudah meratifikasi beberapa perjanjian mengenai penghapusan rasial dan etnis dan telah membuat Undang-undang Nomor 40 Tahun 2008 namun demikian, sudah 12 tahun UU Nomor 40 Tahun 2008 berlaku, tapi pelaksanaannya dinilai belum efektif menjerat pelaku rasisme atau diskriminasi ras dan etnis. Secara peraturan perundangundangan telah berjalan selaras namun dalam implementasinya di lapangan masih minim.

Sebagai contoh, dalam kasus penyerangan mahasiswa Papua yang terjadi di Surabaya pada tahun 2019 lalu, yang dikejar oleh aparat hanyalah tindakan membuat onar bukan tindakan diskriminasi rasial dan etnis, padahal perbuatan dan kasus yang terjadi di Surabaya ini merupakan pelanggaran Hak Asasi Manusia karena sudah melakukan tindakan diskriminasi kepada suatu ras dan etnis tertentu dengan ucapan hinaan, dan juga Indonesia sudah mempunyai Undang-undang Nomor 40 
Tahun 2008 yang dinilai bagus untuk menangani dan menghapus kasus diskriminasi rasial dan etnis namun pelaksanaannya masih kurang efektif.

Dalam mengatasi dan menangani persoalan pelanggaran hak asasi manusia, penegakan hukum menjadi salah satu instrumen yang sangat diperlukan, dan harus sinergis dengan instrumen-instrumen lainnya. Berbagai konflik yang terjadi di Indonesia dan negara-negara ASEAN, termasuk konflik yang mengenai rasial dan etnis akibat dari kombinasi berbagai persoalan kebijakan publik, identitas, efektivitas penegakan hukum, tata kelola pemerintahan yang buruk, dan perebutan sumber daya alam. Penegakan hukum memang tidak hanya berdiri sendiri, namun perlu ditopang dengan adanya reformasi di sektor keamanan yang mengedepankan profesionalisme POLRI dan TNI.

Selama ini yang lebih aktif dalam tackle persoalan diskriminasi rasial dan etnis ini justu organisasi-organisasi internasional seperti NGO (Non Goverment Organization). Pemerintah Indonesia seharusnya memberikan ruang yang cukup bagi orang Papua untuk menyuarakan keresahan mereka terkait diskriminasi. Pemerintah tidak berusaha untuk mendengarkan apa yang sebenarnya orang Papua rasakan, pikirkan dan ingin mencoba disuarakan.
Approach yang dilakukan oleh pemerintah untuk ambil andil terkait penanganan kasus diskriminasi rasial dan etnis ini masih terbilang minim. Pemerintah dianggap tidak tackle dalam masalah inti yaitu pelanggaran hak asasi manusia terkait isu rasial dan etnis, malah pemerintah hanya melakukan deploy tentang military force.

\section{PENUTUP}

\section{Kesimpulan}

Berdasarkan hasil pembahasan, maka dapat disimpulkan: Pertama, Secara peraturan perundang-undangan telah berjalan selaras namun dalam implementasinya di lapangan masih minim, tergambarkan melalui masih kurangnya sosialisasi yang dilakukan terkait regulasi diskriminasi rasial dan etnis yang ada serta masih maraknya pelanggaran berupa penghinaan kepada suatu ras dan etnis tertentu . Kedua, Sesuai dengan kajian hukum internasional, pemerintah Indonesia juga melakukan upaya dalam mencegah isu rasial dan etnis dengan meratifikasi berbagai perjanjian internasional yang pada intinya berkomitmen untuk menghapus segala jenis bentuk diskriminasi. Namun tentunya, tidak cukup dengan hanya meratifikasi perjanjian internasional semata, diperlukan kombinasi berbagai aspek seperti kebijakan publik, efektivitas penegakan hukum, harmonisasi tata kelola pemerintahan, dan kebijakan 
pengelolaan sumber daya alam. Terpenting, Pemerintah Indonesia harus memberikan ruang yang cukup bagi orang Papua dalam hal ini, untuk menyuarakan keresahan mereka terkait diskriminasi.

\section{Saran}

Saran peneliti setelah pembahasan sebagai berikut:

1. Pemerintah Indonesia agar lebih melakukan tindakan untuk mengedukasi masyarakat tentang apa itu diskriminasi rasial dan etnis, bagaimana tindakan diskriminasi rasial dan etnis dan mensosialisasikan tentang Undangundang Nomor 40 Tahun 2008 ini lebih banyak lagi agar masyarakat Indonesia bisa mengetahuinya dan berhenti menganggap bahwa ujaran kebencian dan hinaan yang terkait dengan ras dan etnis bukanlah tindakan sepele.

2. Masyarakat harus lebih sadar lagi akan hak, kewajiban serta peran warga negara yang masih sering dikesampingkan, karena pada kenyataannya masih banyak warga negara Indonesia sendiri yang melemparkan ujaran kebencian, bahkan candaan yang biasa disebut "candaan rasis".

\section{REFERENSI}

\section{Buku}

Marzuki, Peter M. (2011), Penelitian Hukum. Kencana Prenada Media Group.
Soekanto, Soerjono. (2004), Penelitian Hukum

Normatif. PT. Raja Grafindo Persada.

\section{Jurnal}

Achir, N. (2020, Januari). Anotasi Normatif Terhadap Peraturan Daerah Tentang Transparasi. Jambura Law Review, 2 (1), 3.

Lane, M. (2019, September). The Papuan Question in Indonesia: Recent Developments. Researches At Iseas - Yusof Ishak Institute Analyse Current Events. 74, 1.

Pamungkas, C. (2017, November). The Campaign of Papua Peace Network for Papua Peace Land. Jurnal Ilmu Sosial dan Ilmu Politik, 21 (2), 1.

Tijow, L.M. (2020, Oktober). Kedudukan Peraturan Desa Dalam Sistem Pembentukan Peraturan Perundang-undangan Nasional. Jurnal Ius Civile, 4 (2), 1.

Tome, A.H. (2020, Januari). Membumikan Pancasila: Upaya Pelembagaan Nilai Pancasila Dalam Kehidupan Masyarakat Desa, Jurnal Al- 'Adl. 13 (1), 1.

\section{Peraturan Perundang-undangan}

Undang-Undang Dasar Negara Republik Indonesia Tahun 1945. Republik Indonesia, 1945.

Undang-Undang Republik Indonesia Nomor 40 Tahun 2008 Tentang Penghapusan Diskriminasi Ras Dan Etnis.

Undang-Undang Republik Indonesia Nomor 11 Tahun 2005 Tentang Pengesahan Konvenan Internasional Tentang Hak-Hak Ekonomi, Sosial, Dan Budaya.

Undang-Undang Nomor 12 Tahun 2005 
Tentang Pengesahan Konvenan

Internasional Tentang Hak-Hak Sipil Dan

Politik.

Undang-Undang Nomor 39 Tahun 1999

Tentang Hak Asasi Manusia. Universal

Declaration of Human Rights (UDHR) tahun 1948.

\section{Website}

Bernie, Mohammad. (2019, Agustus). dilansir berita tirto.id. Retrieved Oktober 25 2020, from tirto.id:

https://tirto.id/kronologi-penyeranganasrama-papua-di-makassar-versimahasiswa-egAI

Bhaskara, Ign. L. Adhi. (2018, November). dilansir dari tirto.id. Retrieved Oktober 24 2020, from tirto.id: https://tirto.id/survei-komnas-hamdiskriminasi-etnis-ras-masih-terusditolerir-dahP

Ratnasari, Fadhila Eka. (2020, Oktober). dilansir dari Berita Politik Dunia. Retrieved Oktober 25 2020, from Berita Politik Dunia: https://matamatapolitik.com/membicar akan-diskriminasi-atas-papua-danrasisme-di-indonesia-analisis/

Satria, Jefrie Nandy. (2019, Agustus). dilansir dari detikNews. Retrieved Desember 22 2020, from News Detik: https://news.detik.com/berita/d-

4676722/ylbhi-kecam-dugaan- diskriminasi-pada-mahasiswa-papua-disurabaya 